\title{
Anti-Angiogenic Properties of Ginsenoside Rg3
}

\author{
Maryam Nakhjavani ${ }^{1,2}\left(\mathbb{D}\right.$, Eric Smith ${ }^{1,2}{ }^{-}$, Amanda R. Townsend ${ }^{2,3}$, Timothy J. Price ${ }^{2,3}$ and \\ Jennifer E. Hardingham $1,2, *$ (i) \\ 1 Molecular Oncology, Basil Hetzel Institute for Translational Health Research, The Queen Elizabeth Hospital, \\ Woodville South, SA 5011, Australia; maryam.nakhjavani@adelaide.edu.au (M.N.); \\ eric.smith@adelaide.edu.au (E.S.) \\ 2 Adelaide Medical School, University of Adelaide, Adelaide, SA 5005, Australia; \\ amanda.townsend@sa.gov.au (A.R.T.); timothy.price@sa.gov.au (T.J.P.) \\ 3 Medical Oncology Unit, The Queen Elizabeth Hospital, Woodville South, SA 5011, Australia \\ * Correspondence: jennifer.hardingham@adelaide.edu.au; Tel.: +61-8-8222-6142
}

Academic Editor: Deok-Chun Yang

Received: 24 June 2020; Accepted: 21 October 2020; Published: 23 October 2020

check for updates

\begin{abstract}
Ginsenoside $\operatorname{Rg} 3(\operatorname{Rg} 3)$ is a member of the ginsenoside family of chemicals extracted from Panax ginseng. Like other ginsenosides, Rg3 has two epimers: 20(S)-ginsenoside Rg3 (SRg3) and 20(R)-ginsenoside Rg3 (RRg3). Rg3 is an intriguing molecule due to its anti-cancer properties. One facet of the anti-cancer properties of $\mathrm{Rg} 3$ is the anti-angiogenic action. This review describes the controversies on the effects and effective dose range of $\mathrm{Rg} 3$, summarizes the evidence on the efficacy of $\operatorname{Rg} 3$ on angiogenesis, and raises the possibility that $\operatorname{Rg} 3$ is a prodrug.
\end{abstract}

Keywords: ginsenoside Rg3; 20(S)-ginsenoside Rg3; 20(R)-ginsenoside Rg3; angiogenesis; epimer

\section{Introduction}

The root of the plant Panax ginseng C.A. Meyer, commonly known as ginseng, has been used as a traditional medicine in Asian countries for thousands of years. It was primarily used as a food and source of energy and strength. Gradually several pharmacological effects of ginseng on immune function, cardiovascular system, neurological disorders and cancer treatment were discovered [1]. The major bioactive components of ginseng responsible for its pharmacological action are ginsenoside saponins. The general structure of ginsenosides is a four-ring steroid backbone with hydrophobic properties, which is connected to sugar molecules, responsible for the hydrophilicity of the molecule. Based on the positioning of hydrogen on carbon 20 (C20), ginsenosides have two stereoisomers; 20(S) and 20(R) epimers. Ginsenoside Rg3 (Rg3) is a member of the ginsenoside family of saponins, and like other members, Rg3 has two epimers, 20(S)-ginsenoside Rg3 (SRg3) and 20(R)-ginsenoside Rg3 (RRg3) (Figure 1).

Steam heating the white fresh ginseng for several hours prepares red ginseng which has improved pharmacological efficacy and is enriched for some ginsenosides including $\operatorname{Rg} 3[2,3]$. This process produces mainly SRg3 as the major epimer. Furthermore, enzymatic hydrolysis [4,5] or alkali hydrolysis [6] are other methods of preparation of SRg3. However, production of RRg3 requires procedures that are more complex [7]. The quantity of $\mathrm{Rg} 3$ in red ginseng is very much dependent on the method of preparation and various methods have resulted in various contents, for example, $1.2 \mathrm{mg} / \mathrm{mL} \mathrm{Rg} 3$ was recovered by Phellinus linteus fermentation method [8]. The steaming condition also results in different amounts of $\mathrm{Rg} 3$ as reported by different studies such as $25 \mu \mathrm{g} / \mathrm{mL}$ [9], $39 \mathrm{mg} / \mathrm{g}$ [2] or $0.28 \% w / w[10]$. 

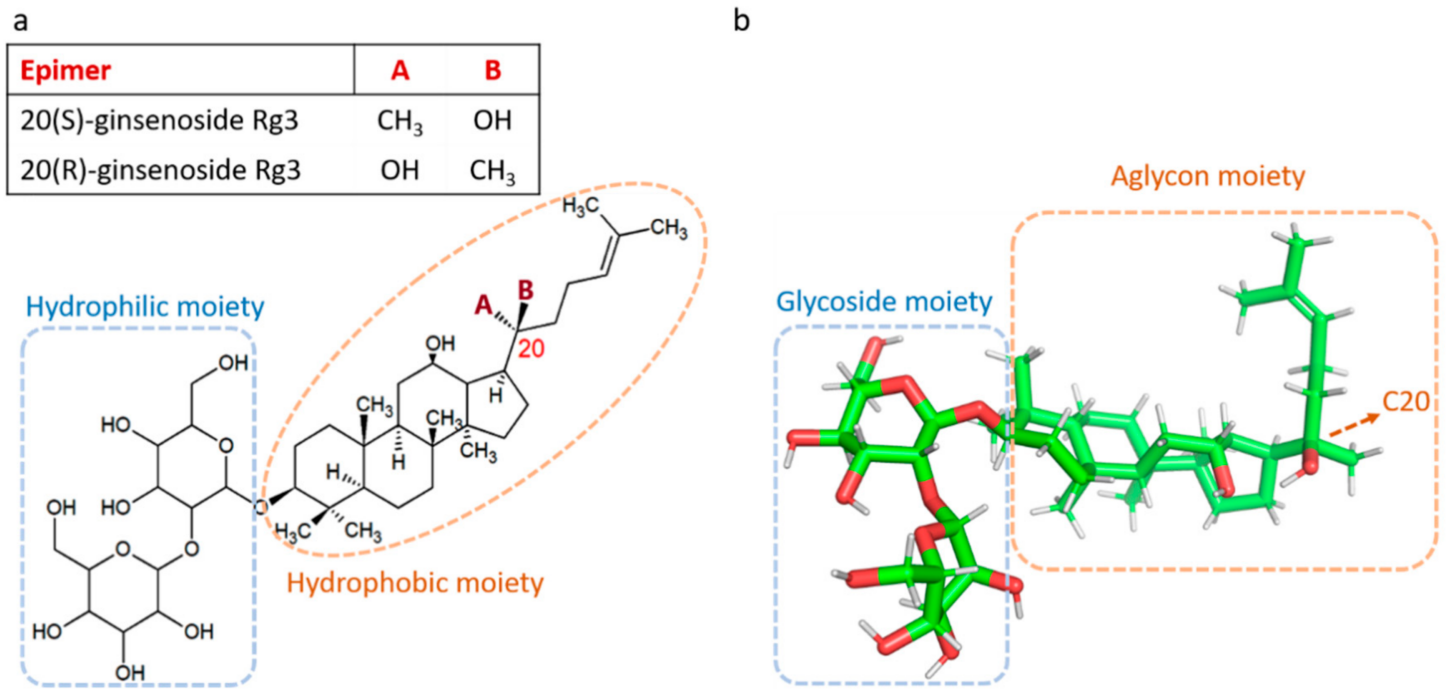

Figure 1. Structure of ginsenoside $\operatorname{Rg} 3$ as 2D (a) and 3D, generated in UCSF Chimera program (b), showing the chiral center at carbon 20, aglycone steroid-like backbone with hydrophobic properties and glycoside hydrophilic moiety, responsible for the water solubility of ginsenoside $\operatorname{Rg} 3(\operatorname{Rg} 3)$.

Rg3 is one of the most studied and pharmacologically active ginsenosides, with stereoselective activities by the epimers SRg3 and RRg3 [11,12]. The chemistry of Rg3 epimers could explain this stereoselective activity. For example, stereoselective activity of $\mathrm{Rg} 3$ epimers in interaction with $\mathrm{Na}^{+}$ channels has been described [13]. Positioning of hydroxyl on C20 seems to play an important role in the pharmacological effects of Rg3. The alkene chain in the aglycone moiety of $\operatorname{Rg} 3$ (Figure 1) produces a tight hydrophobic packing near C20 which makes it inaccessible to water molecules, facilitates hydrophobic bonding between $\mathrm{SRg} 3$ and $\mathrm{Na}^{+}$ion channels and makes a more stabilized hydrogen binding between the two [13].

One of the important properties of $\mathrm{Rg} 3$ is its anti-cancer properties. The mechanisms of Rg3 in inhibition of proliferation, migration and invasion of cancer cells was reviewed previously [11]. Angiogenesis plays a major role in the growth and metastasis of a tumor and one of the important properties of $\mathrm{Rg} 3$ is its action on angiogenesis. This review paper aims to look at the different aspects of anti-angiogenic properties of Rg3, using PubMed as the search engine with Mesh terms ginsenoside Rg3 and angiogenesis for all published papers between 1995 and 2020. The first study demonstrating the anti-angiogenic properties of Rg3 was published by Mochizuki et al. in 1995 [14]. They showed in a mouse model of metastatic melanoma that $100 \mu \mathrm{g} /$ mouse intravenous (i.v.) or $300 \mu \mathrm{g} / \mathrm{mouse}$ oral (p.o.) of either epimer inhibited the formation of vessels oriented towards the tumor mass. This animal study was, however, a short-term study (6 days), with only three mice per group. It was a remarkable study in the area since it not only demonstrated the anti-angiogenic potential of $\operatorname{Rg} 3$ in vivo, but also tested both epimers, separately [14]. This is especially important since most of the research published on Rg3 has not described which specific epimer was studied. Since then, several studies have been conducted in vitro and in vivo, which are reviewed here.

\section{The Controversies on the Effects of Rg3 on Angiogenesis}

Studying the proliferation and tube formation of human umbilical vein endothelial cells (HUVECs) on a layer of Matrigel is the mainstay of drug studies investigating anti-angiogenic properties. With $\mathrm{Rg} 3$, both of these aspects are a matter of controversy. A few studies have shown that the effective concentration of $\mathrm{Rg} 3$ for inhibition of loop formation was at nM ranges (Table 1) [15-19]. For example, RRg3 at 1-1000 nM inhibited tube-formation and chemotactic migration of HUVECs. At this concentration, RRg3 also decreased microvascular sprouting and hemoglobin content of tumors (in a Matrigel plug assay) [15]. Concentrations as low as $1.3 \mu \mathrm{M} \mathrm{Rg}$ (not as a specific epimer) 
inhibited tube-forming capacity of HUVECs and hemoglobin content of Matrigel plugs [16]. At 60 and $300 \mathrm{ng} / \mathrm{mL}$, Rg3 showed effectiveness in inhibition of differentiation of endothelial progenitor cells (EPCs) [18], though it did not inhibit the proliferation of these cells [17]. Although these studies showed the effectiveness of nM concentrations of $\mathrm{Rg} 3$, other studies tested higher doses at $\mu \mathrm{M}$ scale and in most cases showed anti-angiogenic properties. The exceptions are the studies that suggested $\mathrm{Rg} 3$ at $\mu \mathrm{M}$ concentrations was proangiogenic (Table 1) [20,21].

Table 1. Controversies on the proangiogenic or anti-angiogenic effects of $\mathrm{Rg} 3$ on endothelial cells.

\begin{tabular}{|c|c|c|c|c|c|}
\hline & Epimer & Concentration & Tested Cell & Effect & Ref \\
\hline \multirow{5}{*}{ Anti-angiogenic } & RRg3 & $1-1000 \mathrm{nM}$ & HUVEC & $\begin{array}{c}\downarrow \text { tube-formation } \\
\downarrow \text { chemotactic migration } \\
\downarrow \text { microvascular sprouting } \\
\downarrow \text { hemoglobin content of tumors }\end{array}$ & [15] \\
\hline & $\operatorname{Rg} 3$ & $1.3 \mu \mathrm{M}$ & HUVEC & $\begin{array}{c}\downarrow \text { tube-forming capacity } \\
\downarrow \text { hemoglobin content of Matrigel } \\
\text { plugs }\end{array}$ & [16] \\
\hline & $\operatorname{Rg} 3$ & $\begin{array}{l}60-600 \\
\mathrm{~nm} / \mathrm{mL}\end{array}$ & EPC & $\begin{array}{c}\downarrow \text { expression of VEGF and VEGFR2 } \\
\downarrow \text { proliferation, migration and tube } \\
\text { formation }\end{array}$ & [17] \\
\hline & $\operatorname{Rg} 3$ & $60,300 \mathrm{ng} / \mathrm{mL}$ & EPC & inhibition of differentiation & [18] \\
\hline & RRg3 & $100 \mathrm{nM}$ & HUVEC & $\begin{array}{c}\uparrow \text { miR-520h } \\
\downarrow \text { EphB2 and EphB4 } \\
\downarrow \text { proliferation and loop formation }\end{array}$ & [19] \\
\hline \multirow{3}{*}{ Pro-angiogenic } & $\operatorname{Rg} 3$ & $1-10 \mu \mathrm{g} / \mathrm{mL}$ & ECV 304 & $\begin{array}{l}\uparrow \text { expression and phosphorylation of } \\
\text { eNOS } \\
\uparrow \text { expression of PI3K, JNK, p38 MAPK } \\
\uparrow \text { gene transcription mediated by ER } \\
\text { and GR } \\
\text { 个 CaMK-II and AMPK }\end{array}$ & [21] \\
\hline & SRg3 & $15 \mu \mathrm{M}$ & HUVEC & $\begin{array}{c}\uparrow \text { proliferation (50\%) } \\
\uparrow \text { DNA synthesis } \\
\uparrow \text { migration } \\
\uparrow \text { loop formation } \\
\uparrow \text { activation of ERK/Akt/eNOS } \\
\uparrow \text { activation of PPAR } \gamma\end{array}$ & [20] \\
\hline & $\operatorname{RRg} 3$ & $15 \mu \mathrm{M}$ & HUVEC & $\begin{array}{l}\uparrow \text { proliferation }(10 \%) \\
\uparrow \text { loop formation }\end{array}$ & \\
\hline \multirow{2}{*}{ Anti-angiogenic } & RRg3 & $65 \mu \mathrm{M}$ & HUVEC & $\begin{array}{c}\downarrow \text { tube formation and migration } \\
\downarrow \text { protein and transcript expression of } \\
\text { VEGF, b-FGF, MMP-2, MMP-9 }\end{array}$ & [22] \\
\hline & $\operatorname{Rg} 3$ & $180 \mu \mathrm{g} / \mathrm{mL}$ & HUVEC & $\begin{array}{c}\downarrow \text { proliferation } \\
\downarrow \text { expression of VEGF and Bcl-2 } \\
\text { S-phase cell cycle arrest }\end{array}$ & [23] \\
\hline
\end{tabular}

The study by Kwok et al. showed that $15 \mu \mathrm{M}$ of SRg3 and RRg3 increased the rate of proliferation by 50 and $10 \%$, respectively. Only SRg3 induced DNA synthesis $(15 \mu \mathrm{M})$ and migration of HUVECs $(15-30 \mu \mathrm{M})$. SRg3 and to a lower degree RRg3, increased loop formation in HUVECs. Exposing the cells with SRg3 and not RRg3 led to a prompt and continuous activation of extracellular signal-regulated kinase (ERK) followed by activation of Akt (phosphorylation at Ser473) and endothelial nitric oxide synthase (eNOS) (phosphorylation at Ser1177). It also showed that these two epimers, stereoselectively and with different potencies, interact with and activate peroxisome proliferator-activated receptor-gamma (PPAR $\gamma$ ) [20]. PPAR $\gamma$ is one of the ligand-dependent transcriptional factors with polyunsaturated fatty acids as its endogenous ligands. One of the roles of 
PPAR $\gamma$ is in regulating angiogenesis [20,24] and they showed that the activation of ERK/Akt/eNOS pathway by $\operatorname{Rg} 3$ is dependent on the activation of PPAR $\gamma$. It is noteworthy that in this study, instead of vascular endothelial growth factor (VEGF) as a supplement for the growth of HUVECs, fetal bovine serum was used. This might explain the observed controversy in the literature (see Section 3 ).

Other studies showed anti-angiogenic effects of $\operatorname{Rg} 3$ at $\mu \mathrm{M}$ range. At $65 \mu \mathrm{M}, \operatorname{Rg} 3$ inhibited tube formation and migration. This inhibition was associated with decreased protein and transcript expression of vascular endothelial growth factor (VEGF), basic fibroblast growth factor (b-FGF) and matrix metalloproteinase-2 (MMP-2) and protein expression of MMP-9 [22]. The anti-angiogenic properties of $\operatorname{Rg} 3$ were also studied in combination with temozolomide. Temozolomide is one of the effective drugs to improve survival rate and progression-free survival of glioblastoma patients. In a study by Sun et al., the in vitro data suggested that the combination of the oral chemotherapeutic temozolomide $(10 \mu \mathrm{g} / \mathrm{mL})$ and $\operatorname{Rg} 3(10 \mu \mathrm{g} / \mathrm{mL})$ had additive effects on inhibition of HUVEC proliferation [23]. At $180 \mu \mathrm{g} / \mathrm{mL}$, temozolomide and $180 \mu \mathrm{g} / \mathrm{mL} \operatorname{Rg} 3$ (144 h), inhibition of proliferation was observed in HUVECs. This combination also decreased the transcript expression of VEGF and Bcl-2, a regulator of apoptosis that inhibits the function of proapoptotic proteins, in HUVECs [23].

Other than the reported controversy about the pro- or anti-angiogenic effect of $\operatorname{Rg} 3$ at $\mu \mathrm{M}$ range, some studies have not shown an anti-proliferative effect of Rg3 on HUVECs. For example, $50 \mu \mathrm{g} / \mathrm{mL}$ $\mathrm{Rg} 3$ did not inhibit the proliferation of HUVECs within $72 \mathrm{~h}$ [22] and the anti-proliferative effect at 1-1000 nM, while significant, was very weak and not dose-dependent [15]. A time- and dose-dependent inhibition of proliferation of HUVECs was reported with Rg3 (0-180 $\mu \mathrm{g} / \mathrm{mL})$. At $180 \mu \mathrm{g} / \mathrm{mL}(144 \mathrm{~h})$ about $28 \%$ inhibition of proliferation was observed. $\mathrm{Rg} 3$ at these concentrations induced S-phase cell cycle arrest (not time-dependent). Exposure of HUVECs for $72 \mathrm{~h}$ to $\mathrm{Rg} 3(80 \mu \mathrm{g} / \mathrm{mL}) \mathrm{decreased}$ the expression of VEGF and Bcl-2 [23].

\section{Pharmacodynamic Aspects of the Effect of Rg3 on Angiogenesis}

To address the question about controversies on the effects of $\mathrm{Rg} 3$ on angiogenesis at various concertation ranges, the possible explanations might depend on the pharmacodynamics of the interaction of Rg3 with its receptors. VEGF is the main ligand to its receptor, VEGFR2, the interaction of which plays the key role in angiogenesis. Any full agonist binds to the same binding site of VEGF on VEGFR2 and mimics the action of VEGF, leading to a maximal effect (Emax).

One possible explanation could be that $\mathrm{Rg} 3$ might be a partial agonist at $\mathrm{nM}$ concentrations. A partial agonist, in the absence of an agonist activates the receptor, while in the presence of agonist acts like an antagonist. In vitro assays with endothelial cells usually use a constant concentration of VEGF in the media. This concentration is usually low and at the levels of $\mathrm{ng} / \mathrm{mL}$. At nM concentrations, $\mathrm{Rg} 3$, if considered as a partial agonist, and in the presence of a constant level of VEGF, might have a role of a competitive antagonist for VEGFR2. At higher concentrations it could act as an agonist of the receptor. Two examples of the anti- and pro-angiogenic effects of Rg3 on HUVECs were discussed above. At nM concentrations and in the presence of VEGF, RRg3 showed anti-angiogenic affects [15] and at low $\mu \mathrm{M}$ range (up to $30 \mu \mathrm{M}$ ) in the presence of fetal bovine serum, $\operatorname{Rg} 3$ had pro-angiogenic effects [20]. Therefore, at nM range and in the presence of VEGF, $\operatorname{Rg} 3$ acted as an antagonist and in the absence of VEGF acted as agonist.

The other explanation is the possibility of Rg3 having a biphasic U-shaped dose-response curve. In that case, $\operatorname{Rg} 3$ would be one of the many examples of molecules having such a biphasic dose-response curve. Examples of such molecules are estrogens [25], NO [26], cadmium and mercury [27], opiates [28], dopamine [29], and anti-angiogenic agents such as endostatin [30], statins [31], captopril [32] and interferon-alpha [33].

However, as described above and previously reviewed [11], there are many studies that used and showed the efficacy of $\mathrm{Rg} 3$ at high $\mu \mathrm{M}$ ranges up to $230 \mu \mathrm{M}(180 \mu \mathrm{g} / \mathrm{mL})$ [23]. This opens another 
window for $\mathrm{Rg} 3$ to have a triphasic dose-response. Examples of molecules with triphasic dose-response are vasopressin [34], neurotensin [35] and amphetamine [36].

\section{Molecular Mechanisms of Rg3 in Targeting Angiogenesis}

When the balance between pro- and anti-angiogenic agents shifts towards pro-angiogenic agents including VEGF, as a fundamental player, and other factors such as b-FGF, epidermal growth factor (EGF), transforming growth factor $\beta$ (TGF- $\beta$ ), tumor necrosis factor-alpha (TNF- $\alpha$ ), angiogenin, angiopoietin, and interleukin 8 (IL-8) [37], several intracellular pathways are triggered leading to activation of endothelial cell proliferation and migration towards the tumor. Migration of endothelial cells is a complex process which requires coordination of several cellular components and changes the dynamic of cellular compartments. Below, the molecules and signaling pathways that are affected following administration of $\mathrm{Rg} 3$ are discussed.

\subsection{VEGF and its Receptor, VEGFR2}

VEGFR2, a receptor tyrosine kinase (RTK), is one of the three subtypes of VEGF receptor. The interaction between VEGF and VEGFR2 is known as the key driver of angiogenesis (Figure 2a). One of the commonly described mechanisms of inhibition of angiogenesis is decreased expression or availability of VEGF and VEGFR2. Rg3 inhibited the protein expression of VEGF in human hepatocellular (HepG2) [38], esophageal (Eca-109) and renal cell carcinoma (786-0) cell lines [39], decreased VEGF-A and -C in anaplastic thyroid and papillary thyroid cancer cell lines [40] and decreased transcripts of VEGF-A, -B and -C in a mouse model of breast cancer [25]. In hypertrophic scar fibroblasts, RRg3 inhibited the transcript and protein expression of VEGF [41]. Likewise, a decreased expression of VEGFR2 was shown in EPCs [17]. Many in vivo studies also showed a decreased expression of VEGF and VEGFR2 (Table 2). The mechanisms involved in such decreased expression of these factors could be explained by the inhibitory action of $\operatorname{Rg} 3$ on the expression of hypoxia inducible factor- $1 \alpha$ (HIF-1 $\alpha$ ), cyclooxygenase-2 (COX-2) and nuclear factor- $\mathrm{kB}$ (NF-kB) [39]. The VEGF promoter has a hypoxia-responsive element which upon binding to HIF- $1 \alpha$, activates the expression of VEGF [42]. Hypoxia also regulates the expression of COX-2, the expression of which correlates with VEGF [43]. NF- $\mathrm{KB}$ is a regulator of various cellular processes that lead to tumorigenesis and metastasis. Angiogenesis is one of these processes. P65 is one of the important members of NF-kB family, the expression of which was inhibited by $\operatorname{Rg} 3$ [39].

At least four major downstream intracellular signaling pathways are involved in VEGFR2 activation (reviewed in [44]). The major pathway is the activation of phospholipase $C \gamma$, which can activate a number of downstream signaling molecules and pathways including protein kinase C/Raf/MEK/ERK [45,46]. Activation of this pathway leads to cell proliferation, survival and migration. Another pathway is PI3K/Akt/mTOR pathway which is involved in cell survival and regulation of migration [47]. The third signaling pathway includes SRC and small GTPases that are involved in cell polarization, shape and migration [48]. A fourth signaling pathway involves molecules downstream of VEGFR2 activation: stress kinases such as STATs, G protein-coupled receptor-dependent signaling and p38 MAPK [44]. The specific action of Rg3 on some of the pathways has been elucidated (Figure 2); some of the explored signaling pathways which play roles in angiogenesis are described below. 


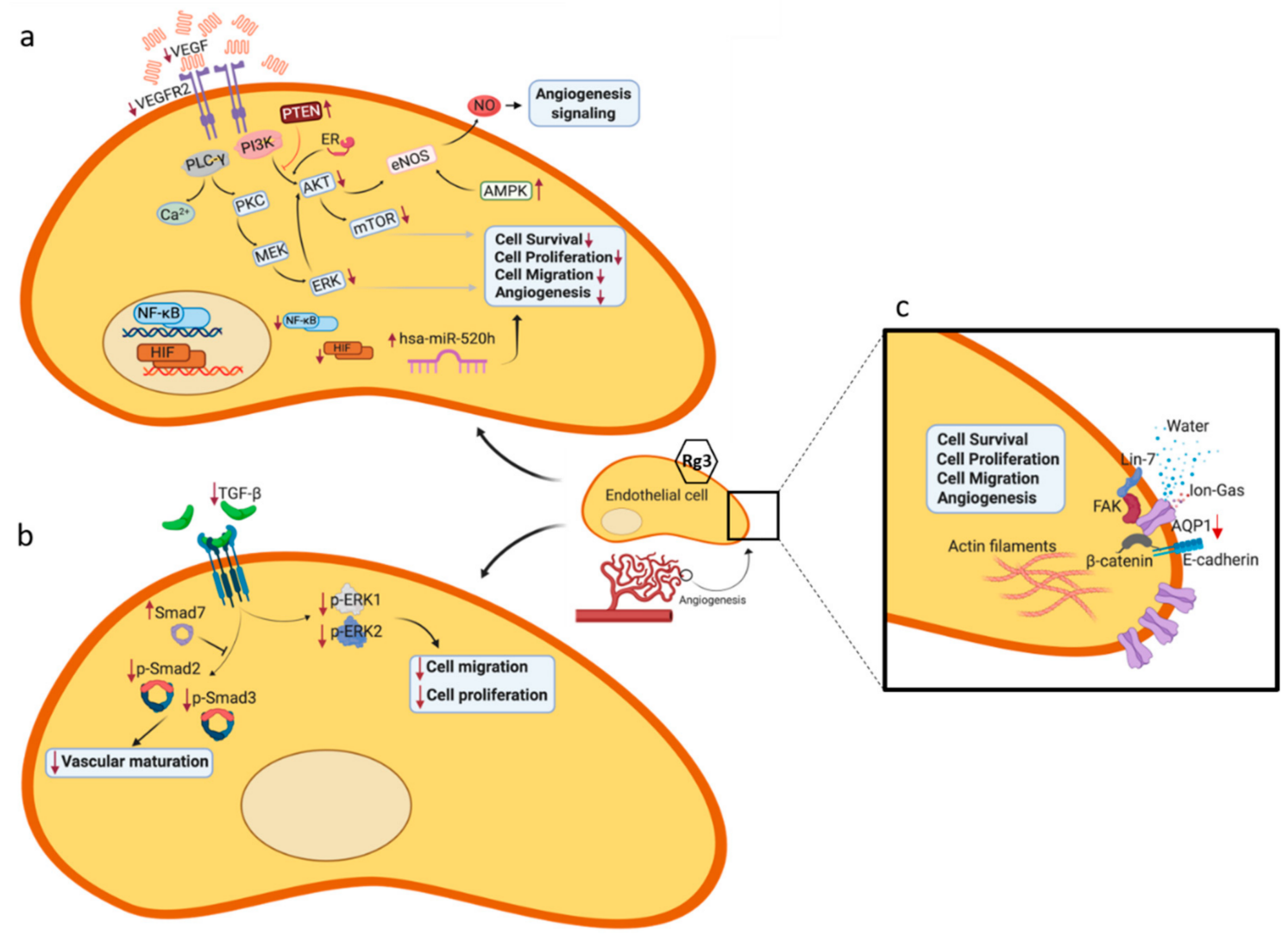

Figure 2. Signaling molecules and pathways that are affected by Rg3 in an endothelial cell. (a) VEGF-VEGFR2 interaction and inhibition of the related signaling pathways and molecules, (b) decreased expression of TGF- $\beta 1$ and the related signaling molecules, (c) blocking the water transport function of AQP1 and decreased expression of AQP1. Red arrows $\downarrow$ and $\uparrow$ show the effect of $\operatorname{Rg} 3$ on decreased and increased expression of molecules, respectively.

Table 2. Antiangiogenic properties of Rg3 studied in different cancer models.

\begin{tabular}{|c|c|c|c|c|c|}
\hline Cancer & $\begin{array}{l}\text { Animal } \\
\text { Model }\end{array}$ & $\begin{array}{l}\text { Rg3, Dose and } \\
\text { Route of } \\
\text { Administration }\end{array}$ & $\begin{array}{l}\text { Other Drugs in } \\
\text { Study }\end{array}$ & Results & Ref \\
\hline \multirow[b]{2}{*}{ Breast } & $\begin{array}{l}\mathrm{BALB} / \mathrm{c} \\
\text { mouse }\end{array}$ & $\begin{array}{l}10 \mathrm{mg} / \mathrm{kg} / \text { day, } \\
\text { p.o. }\end{array}$ & $\begin{array}{l}\text { Low dose } \\
\text { capecitabine, } \\
200 \mathrm{mg} / \mathrm{kg} / \text { day, } \\
\text { p.o. }\end{array}$ & $\begin{array}{c}\downarrow \text { MVD }^{\mathrm{a}} \text { and VEGF expression } \\
\text { (especially in the combination } \\
\text { group) }\end{array}$ & [49] \\
\hline & $\begin{array}{l}\text { Nude } \\
\text { mouse }\end{array}$ & $\begin{array}{l}5 \mathrm{mg} / \mathrm{kg} \text { q.a.d., } \\
\text { s.c. }\end{array}$ & $\begin{array}{l}\text { Recombinant } \\
\text { human } \\
\text { endostatin, } \\
10 \mathrm{mg} / \mathrm{kg} \text {, q.a.d. }\end{array}$ & $\begin{array}{c}\downarrow \text { VEGF-A, -B, -C (especially in } \\
\text { the combination group), proteins } \\
\text { involved in autophagy pathway, } \\
\text { mTOR, PI3K, Akt, JNK and } \\
\text { Beclin-1 }\end{array}$ & [50] \\
\hline \multirow[b]{2}{*}{ Ovary } & $\begin{array}{l}\text { Nude } \\
\text { mouse }\end{array}$ & i.p. & Cyclophosphamide & $\begin{array}{c}\downarrow \text { MVD and VEGF expression } \\
\text { (combination) }\end{array}$ & [51] \\
\hline & $\begin{array}{l}\text { Nude } \\
\text { mouse }\end{array}$ & $\begin{array}{l}0.3,1 \text { and } \\
3 \mathrm{mg} / \mathrm{kg} / \mathrm{d} \text { for } \\
20 \text { days, i.p. }\end{array}$ & & $\begin{array}{c}\downarrow \text { number of vessels oriented } \\
\text { toward the tumor mass }\end{array}$ & [52] \\
\hline
\end{tabular}


Table 2. Cont.

\begin{tabular}{|c|c|c|c|c|c|}
\hline Cancer & $\begin{array}{l}\text { Animal } \\
\text { Model }\end{array}$ & $\begin{array}{l}\text { Rg3, Dose and } \\
\text { Route of } \\
\text { Administration }\end{array}$ & $\begin{array}{l}\text { Other Drugs in } \\
\text { Study }\end{array}$ & Results & Ref \\
\hline Uterus & Rats & $\begin{array}{l}5 \text { or } 10 \mathrm{mg} / \mathrm{kg} / \mathrm{d} \\
\quad \text { for } 21 \text { days }\end{array}$ & Gestrinone & $\begin{array}{c}\mathrm{Rg} 3(10 \mathrm{mg} / \mathrm{kg} / \mathrm{d})+\text { gestrinone } \\
\text { significantly decreased } \\
\text { the expression of VEGF, VEGFR2, } \\
\text { p-Akt and p-mTOR, suggesting } \\
\text { Rg3 blocks the effect of VEGFR2 } \\
\text { via PI3K/Akt/mTOR signaling } \\
\text { pathway }\end{array}$ & [53] \\
\hline \multirow[t]{2}{*}{$\begin{array}{l}\text { Colorectal } \\
\text { cancer }\end{array}$} & $\begin{array}{l}\text { Nude } \\
\text { mouse }\end{array}$ & $\begin{array}{l}25 \mathrm{mg} / \mathrm{kg} / \mathrm{d} \text { for } \\
12 \text { days, gastric } \\
\text { perfusion }\end{array}$ & & $\begin{array}{l}\text { Inhibited the expression of } \\
\text { angiogenesis-related genes, MVD } \\
\text { and decreased neo-vessel } \\
\text { formation }\end{array}$ & [54] \\
\hline & $\begin{array}{l}\text { Nude } \\
\text { mouse }\end{array}$ & $\begin{array}{l}10 \mathrm{mg} / \mathrm{kg} / \mathrm{d} \text { for } \\
30 \text { days, p.o. }\end{array}$ & $\begin{array}{l}\text { Radiotherapy } \\
\text { twice weekly ( } 2 \\
\text { Gy) for } 2 \text { weeks }\end{array}$ & $\begin{array}{l}\uparrow \text { effects of radiation on } \\
\text { the expression of CD31 }\end{array}$ & [55] \\
\hline Thyroid & $\begin{array}{l}\text { Nude } \\
\text { mouse }\end{array}$ & $\begin{array}{l}10 \mathrm{mg} / \mathrm{kg} / \mathrm{d} \text {, } \\
\text { intragastric }\end{array}$ & & $\downarrow$ CD31 in the tumors & [40] \\
\hline \multirow{3}{*}{ Lung } & Mouse & $\begin{array}{l}20 \mathrm{mg} / \mathrm{kg} / \text { day } \\
\text { for } 18 \text { days, } \\
\text { (gastric } \\
\text { perfusion) }\end{array}$ & $\begin{array}{l}\text { Gemcitabine, } \\
10 \mathrm{mg} / \mathrm{kg} \text {, i.p. } \\
\text { every 3rd day }\end{array}$ & $\begin{array}{l}\downarrow \text { VEGF expression, MVD and } \\
\text { signals of blood flow and peak } \\
\text { systolic velocity of the tumor }\end{array}$ & [56] \\
\hline & Mouse & $\begin{array}{l}600 \mu \mathrm{g} / \mathrm{kg} / \mathrm{day} \\
\text { (p.o.) for } 23 \\
\text { days }\end{array}$ & & $\begin{array}{c}\downarrow \text { arterial and capillary density, } \\
\text { decreased number of } \\
\text { CD34+/VEGFR2+ EPCs }\end{array}$ & [17] \\
\hline & $\begin{array}{l}\text { Wistar } \\
\text { rats }\end{array}$ & $1 \mathrm{mg} / \mathrm{kg}$ & & $\downarrow$ tumor volume and MVD & [57] \\
\hline \multirow{2}{*}{ Melanoma } & $\begin{array}{l}\text { C57BL/6 } \\
\text { mouse }\end{array}$ & $\begin{array}{l}1.5 \mathrm{mg} / \mathrm{kg} \text { every } \\
\text { other day for } 20 \\
\text { days (i.v.) }\end{array}$ & & $\downarrow$ MVD & [58] \\
\hline & $\begin{array}{l}\text { C57BL/6 } \\
\text { mouse }\end{array}$ & $\begin{array}{l}0.3,1.0 \text { or } \\
3.0 \mathrm{mg} / \mathrm{kg} \operatorname{Rg} 3 \\
\text { (i.p.) for } 10 \\
\text { days }\end{array}$ & $\begin{array}{l}\text { 5-Fluorouracil, } \\
\quad 20 \mathrm{mg} / \mathrm{kg}\end{array}$ & $\begin{array}{c}\downarrow \text { vessel numbers, MVD and VEGF } \\
\text { and proliferating cell nuclear } \\
\text { antigen (PCNA) }\end{array}$ & [59] \\
\hline \multirow[t]{3}{*}{ Liver } & $\begin{array}{l}\text { A } \\
\text { rabbit } \\
\text { model } \\
\text { of liver } \\
\text { VX2 } \\
\text { carcinoma }\end{array}$ & $6 \mathrm{mg} / \mathrm{kg}$ (i.v.) & TAE $^{b}$ & $\begin{array}{l}\downarrow \mathrm{CD} 31 \text { and VEGF and } \uparrow \text { Bcl-2 and } \\
\text { caspase-3 }\end{array}$ & [38] \\
\hline & $\begin{array}{l}\text { Buffalo } \\
\text { rat }\end{array}$ & $1 \mathrm{mg} / \mathrm{kg}$ (i.p.) & TAE $^{b}$ & $\begin{array}{l}\downarrow \text { MVD, CD31 expression, VEGF } \\
\text { overexpression, and VEGFR2 } \\
\text { expression and phosphorylation }\end{array}$ & [60] \\
\hline & $\begin{array}{l}\text { C57BL/6 } \\
\text { mouse }\end{array}$ & $\begin{array}{l}10 \mathrm{mg} / \mathrm{kg} \text { for } 10 \\
\text { days }\end{array}$ & & $\downarrow$ MVD & [61] \\
\hline Glioma & Rat & $\begin{array}{l}10 \mathrm{mg} / \mathrm{kg} / \mathrm{d} \text { for } \\
8 \text { days (p.o.) }\end{array}$ & $\begin{array}{c}\text { LDT }^{\mathrm{c}} \\
5 \mathrm{mg} / \mathrm{kg} / \mathrm{d} \text { for } 8 \\
\text { days } \\
\mathrm{MDT}^{\mathrm{d}} \\
30 \mathrm{mg} / \mathrm{kg} / \mathrm{d} \text { for } 3 \\
\text { days }\end{array}$ & $\begin{array}{c}\uparrow \mathrm{rCBV} \text { e; } \\
\text { Untreated: } 90 \% \\
\text { Rg3: } 65 \% \\
\text { MDT: } 64 \% \\
\text { LDT: } 51 \% \\
\text { LDT + Rg3: } 15 \% . \\
\downarrow \text { MVD }\end{array}$ & [23] \\
\hline
\end{tabular}

\footnotetext{
${ }^{a}$ MVD: microvessel density. ${ }^{b}$ TAE: transcatheter arterial embolization. ${ }^{c}$ LDT: low-dose temozolomide. ${ }^{d}$ MDT:
} maximum-tolerated dose temozolomide. ${ }^{\mathrm{e}} \mathrm{rCBV}$ : relative cerebral blood volume. 


\subsection{Signaling Pathways Leading to Activation of eNOS}

eNOS is one of the important mediators of angiogenesis (Figure 2a) [62]. It was shown that VEGF-induced activation of phosphatidylinositol 3-kinase (PI3K) activates eNOS by phosphorylation at Ser1177 [63]. Akt is one of the major kinases downstream of PI3K, which is activated following VEGF stimulation and plays a role in cell survival [64]. Activated Akt also directly signals activation of eNOS (Figure 2a) [65]. It was shown that $\mathrm{Rg} 3(300 \mathrm{ng} / \mathrm{mL})$ decreased VEGF-dependent Akt/eNOS signaling in EPCs [18]. The effect of ginsenosides [66] and Rg3 [67] on NO production was shown previously. Controversies on the effect of $\mathrm{Rg} 3$ on eNOS and NO production exist: at $10 \mu \mathrm{g} / \mathrm{mL}$, increased NO production was reported to be independent of eNOS in canine carporal smooth muscle [67], however in human ECV 304 endothelial cells, the same concentration of Rg3 increased expression and phosphorylation of eNOS via estrogen receptor (ER)-mediated activation of phosphatidylinositol 3-kinase (PI3-kinase) [21]. Involvement of eNOS for production of NO in the Rg3-treated cells might be a tissue- and species-dependent factor. What is controversial here is whether $\operatorname{Rg} 3$ increases or decreases the activation of eNOS in endothelial cells. It seems that at $300 \mathrm{ng} / \mathrm{mL}$, the activity of eNOS was decreased [18] while at $10 \mu \mathrm{g} / \mathrm{mL}$, this activity was increased [21]. Once again it seems that the effect of $\mathrm{Rg} 3$ is dependent on the range of concentration. At $\mathrm{nM}$ ranges, the activity of eNOS was decreased and at $\mu \mathrm{M}$ ranges, the activity increased. Another regulator of this pathway is a tumor suppressor, phosphatase and tensin homolog deleted on chromosome 10 (PTEN). PTEN is an inhibitor of the PI3K/Akt pathway. In a mouse model of hepatocarcinoma, the mice receiving $5 \mathrm{mg} / \mathrm{kg}$ SRg3 showed a non-significant increase in PTEN and decrease in pAkt, as evidenced by immunohistochemistry staining of the tumors. These changes were potentiated and statistically significant when SRg3 was co-administered with sorafenib [68].

The other pathway for the activation of eNOS is via the ER-mediated activation of PI3K/Akt in endothelial cells (Figure 2a) [69] and $\mathrm{Rg} 3$ at $10 \mu \mathrm{g} / \mathrm{mL}$ activates this pathway [21]. It is not yet examined whether Rg3 has a similar pattern of response at other ranges of concentration. It is noteworthy that the promoter region of VEGF gene has an estrogen response element (ERE) [70] and the expression of VEGF is affected by both ER- $\alpha$ and $-\beta$ [71]. Rg3 has a steroid backbone and could be a potential ligand for ER.

The mitogen-activated protein kinase (MAPK) pathway is also another regulator of eNOS (Figure 2a). Activation of MAPK signaling pathway is dependent on the extracellular stimuli and leads to cell stress response, cell proliferation, apoptosis, motility and differentiation. The MAPK family has four subgroups; the p38 group of protein kinases, c-jun N-terminal or stress-activated protein kinases (JNK/SAPK), extracellular signal-regulated kinases (ERKs) and ERK/big MAP kinase 1 (BMK1) [72]. It was shown that at $10 \mu \mathrm{g} / \mathrm{mL}, \mathrm{Rg} 3$ increased the activities of c-Jun N-terminal kinase (JNK), and p38 MAPK. JNK is responsible for a number of cell functions including angiogenesis. It is responsible for a sustained phosphorylation and activation of VEGFR2 following interaction with VEGF [73] and plays a role in the phosphorylation (Ser1177) and activation of eNOS [74]. Likewise, p38 MAPK is activated by VEGFR2 and is necessary to mediate the shear stress-induced angiogenesis [75]. It also binds to and activates eNOS [76].

The other activator of eNOS is AMP-activated protein kinase (AMPK) (Figure 2a), which is a stress activated kinase. Cellular stresses such as hypoxia activate AMPK [77] followed by phosphorylation (Ser1177) and activation of eNOS [78]. Upstream of AMPK is calmodulin-dependent protein kinase II (CaMK-II). Following exposure of ECV 304 cells with $10 \mu \mathrm{g} / \mathrm{mL}$ Rg3, CaMK-II was phosphorylated and activated leading to activation of AMPK [21]. However, it is not yet clear if $\operatorname{Rg} 3$ has a similar mechanism at $\mathrm{nM}$ or higher $\mu \mathrm{M}$ concentrations.

\subsection{Role of Mammalian Target of Rapamycin (TOR), Angiogenesis and Autophagy}

mTOR plays crucial roles in cell growth and metabolism including lipid and protein synthesis, autophagy, mitochondrial metabolism and biogenesis, and angiogenesis. It is one of the conserved proteins belonging to the PI3K related kinase family sand downstream of activation of PI3K/Akt 
(Figure 2a) [79]. Activation of PI3K/Akt, both in a hypoxia-dependent and -independent manners, increases the expression of VEGF and regulated the expression of $\mathrm{NO}$ and other angiogenic factors. Hence, inhibitors of PI3K/Akt/mTOR pathway inhibit angiogenesis (reviewed in [80]). Cao et al. (2017) studied a rat model of endometriosis that received $10 \mathrm{mg} / \mathrm{kg} / \mathrm{day} \mathrm{Rg} 3$ for 21 days, resulting in blocking the VEGFR2-mediated PI3K/Akt/mTOR signaling pathway. This was evidenced by decreased protein expression of VEGF, phosphorylated Akt and phosphorylated mTOR and transcript expression of VEGF, Akt and mTOR [53]. In mice bearing breast tumors, subcutaneous $\mathrm{Rg} 3(5 \mathrm{mg} / \mathrm{kg})$ alone or in combination with Endostar, a modified recombinant human endostatin, decreased the transcript expression of mTOR, PI3K, Akt [50], a pathway that not only is involved in the regulation of angiogenesis, but also modulates autophagy. This study also showed a decreased transcript expression JNK and of Beclin-1 [50]. JNK/Beclin-1 is a crucial pathway mediating autophagic cell death.

\subsection{Signal Transducer and Activator of Transcription 3 (STAT3)}

STAT3 is one of the important members of the STAT family which plays an important role in angiogenesis, being an activator for the transcription of VEGF [81]. Rg3 inhibited the hypoxia-induced phosphorylation of STAT3, ERK1/2 and JNK in esophageal and renal cell carcinoma lines [39].

\subsection{TGF- $\beta 1$}

TGF- $\beta 1$ is a member of TGF- $\beta$ superfamily of cytokines. Downstream to the activation of TGF- $\beta$ receptors, activation of Smads and Smad-interacting transcription factors play roles in cellular responses. Besides Smads, ERK is also activated as a part of non-Smad signaling of TGF- $\beta$ receptors (Figure 2b).

Development of keloid, a hyper-proliferation in a healing wound, requires angiogenesis. Studies in keloid samples showed that Rg3 inhibited the expression of TGF- $\beta 1$, VEGF and plasminogen activator inhibitor-1 (PAI-1). Smad7, a negative feedback regulator in the TGF- $\beta 1 /$ Smad pathway, was increased and the expression levels of $\mathrm{p}-\mathrm{Smad} 2$ and $\mathrm{p}-\mathrm{Smad} 3$, which are enhanced by TGF- $\beta 1$, were markedly decreased, p-ERK1/2 expression was decreased and the protein expression levels of total Smad2/3 and total ERK1/2 remained almost unchanged [82]. In hypertrophic scar fibroblasts RRg3 inhibited the transcript and protein expression of TGF- $\beta 1$, protein levels of phosphorylated Smad2 and Smad3 and ERK1/2 and transcripts of VEGFR and platelet-derived growth factor and increased the protein level of Smad7 [41].

\subsection{Aquaporin 1 ( $A Q P 1)$}

AQP1 is one of the members of water channel family of AQP proteins. It exists as a homotetramer, with every monomer responsible for the transport of water and the central channel between the four monomers responsible for the transport of ion and gases. The role of AQP1 in angiogenesis has already been discussed in the literature (reviewed in $[11,83]$ ). AQP1 plays key roles in the migration of cells, contributing to several steps including polarization, protrusion, cell adhesion to extracellular matrix (ECM), degradation of extracellular matrix and cell retraction (reviewed in [84]). Signaling of AQP1 in complex with other proteins such as focal adhesion kinase (FAK), $\beta$-catenin, Lin-7 and E-cadherin, facilitates the migration of cells (Figure 2c). Lin-7 is one of the proteins that accumulate at cadherin-catenin junctions [85]. The lin- $7 / \beta$-catenin complex is also in interaction with AQP1 playing a role in the effects mediated by AQP1. Lin-7 is one of the scaffolding proteins, with the major role of assembling components of a functional complex of receptors, channels, signaling and adhesion molecules [86]. Moreover, at focal adhesion sites, integrins link the extracellular matrix and the actin cytoskeleton. FAK is another scaffolding protein functioning at these sites and regulating the interaction of proteins. It was shown that there is a functional cross talk between AQP1 and FAK. AQP1 regulates the expression of FAK and FAK colocalizes with AQP1 [87]. AQP1 also regulates the expression of $\beta$-catenin [87] and was also shown to be related to the expression of MMP-2 and -9 [88]. AQP1 also plays a role in regulating cell proliferation via regulating the expression of key cell cycle proteins 
such as cyclin D1 and E1 [89] and transport of oxygen reactive species (ROS), hydrogen peroxide $\left(\mathrm{H}_{2} \mathrm{O}_{2}\right)$ [90], the signaling of which plays a role in proliferation, migration and angiogenesis [91]. In addition, increased mitochondrial ROS enhances necroptotic signaling [92] and AQP1, via effluxing ROS to the extracellular space, can potentially inhibit ROS-induced necroptosis thereby increasing cell survival.

AQP1 plays a fundamental role in the proliferation and migration of endothelial cells during angiogenesis; it is abundantly expressed in tumor microvessels and in endothelial cells in culture [83]. AQP1 has been identified as a promoter of angiogenesis [93], disruption of which impairs angiogenesis [94]. The promoter of Aqp1 has a hypoxia response element, and following hypoxia, not only the transcription of VEGF but also AQP1 was increased [95]. This is in agreement with AQP1 as an anti-angiogenesis target. We have shown that blockers of the AQP1 water channel such as AqB013 [96], AqB050 [97] and bacopaside II [98] inhibit tube formation in endothelial cells. We have also shown that SRg3 stereoselectively inhibited AQP1-mediated transport of water [12]. Decreased expression of AQP1 with Rg3 treatment was also shown in a prostate cancer cell line [99]. This opens new windows for further investigations of the role of AQP1 as a target of Rg3 in inhibiting angiogenesis.

\subsection{MicroRNAs (miRs)}

One of the anti-angiogenic mechanisms suggested for $\mathrm{Rg} 3$ is via miR regulation of angiogenic pathways (Figure 2a). Keung et al. [19] screened human miR and found that in RRg3-treated HUVECs, nine miRs were differentially expressed. Based on microarray data, both hsa-miR-520h and hsa-miR-487b were increased $>10$ fold and hsa-miR-219, hsa-miR-342, hsa-miR-524-5p, and hsa-miR -197 were increased 2-7 fold. Additionally, hsa-miR-23a, hsa-miR-489, and hsa-miR-377 were down regulated (4 to 35 fold). In validation studies they showed a 3-fold increase in the transcripts of hsa-miR-520h in RRg3-treated cells and suggested EphB2 and EphB4 as target genes for hsa-miR-540h. EphB2 and EphB4 are two proteins of the Eph family, the largest RTK family, which upon activation mediate critical steps in cancer cell migration and angiogenesis. This study also showed that overexpression of hsa-miR-520h inhibited the proliferation and tube-forming capacity of HUVECs by 18 and 35\%, respectively. Injection of hsa-miR-520h into the zebra-fish embryos showed that hsa-miR-520h significantly inhibited the neovessel formation. Knock-down of hsa-miR-520h expression significantly reduced the endogenous hsa-miR-520h level in HUVECs, their proliferation and tube-forming capacity [19]. Overall, this study showed that RRg3, potentially, via targeting hsa-miR-520h, suppressed the expression of EphB2 and EphB4 and inhibited angiogenesis.

\subsection{CD31 and CD34}

Cluster of differentiation (CD) 31 and CD34 are two of the surface molecules that have been studied as a marker of angiogenesis in many studies. These proteins are involved in angiogenesis and migration of endothelial cells. Rg3 decreased expression of CD34 in EPCs [18] and decreased expression of CD31 and CD34 in cultured patient keloid samples, by 50 and 65\%, respectively [82]. Several animal studies have also demonstrated decreases in CD31 expression in tumors following treatment with $\operatorname{Rg} 3$ (Table 2).

\section{Pharmacokinetic Aspects of Administering Rg3}

In various in vivo models of cancer, $\mathrm{Rg} 3$ has been administered alone or in combination with other treatments to study the anti-angiogenic properties of this potential drug. Table 2 summarizes these studies' doses and routes of administration and the major anti-angiogenic outcomes of the studies. These studies used doses up to $20 \mathrm{mg} / \mathrm{kg}$ and the drug was administered either p.o., i.v., intraperitoneally (i.p.) or subcutaneously (s.c.).

Depending on the structure of any drug candidate, route of drug administration might have a major role in the disposition of a drug. Among the four determinants of pharmacokinetics, absorption, distribution, metabolism and elimination, the most important determinant to consider 
for administration of $\mathrm{Rg} 3$ seems to be metabolism. From this perspective Rg3 might not be the best candidate for oral administration. It is rapidly metabolized in the gastrointestinal tract (GIT), going through partial or complete hydrolysis in the stomach and losing the sugar moieties by the GIT anaerobic microflora, leaving de-glycosylated active anti-cancer metabolites such as ginsenoside $\mathrm{Rh} 2$ and protopanaxadiol (PPD) [100-102]. Rg3 is also a substrate for cytochrome P450 members, which are abundant in the liver and GIT and also found in other organs including skin, blood, lungs and kidneys. This means that Rg3 is a potential substrate for metabolism in any of these organs [11]. Oral administration could facilitate Rg3 metabolism. However, there are controversies in the literature in terms of the concentration of $\mathrm{Rg} 3$ detected in the blood following oral administration. Plasma detection of Rg3 after oral administration of $10 \mathrm{mg} / \mathrm{kg}$ in Sprague-Dawley rats lasted for $12 \mathrm{~h} \mathrm{[103]} \mathrm{and} \mathrm{after}$ 50 [104] and $100 \mathrm{mg} / \mathrm{kg}$ [105] was not detectable. The absolute bioavailability of $\mathrm{Rg} 3$ was calculated to be $2.63 \%$ [103]. In addition, Rg3 has a relatively high lipophilicity (estimated log P 4) (PubChem) and a low water solubility at $\mathrm{pH} 7.4$ (estimated $\log \mathrm{S}-4.04$ ) (ChemAxon). These, together with the 8 $\mathrm{H}$-bond donors and 13 oxygens in the structure of $\mathrm{Rg} 3$, make it a molecule with low permeability and low bioavailability. This also shows that Rg3 is a violation of Lipinski's "rule of five" which makes it an inappropriate candidate for oral administration [106].

The i.p. administration bypasses the GIT metabolism, but the drug will still be exposed to the liver metabolizing enzymes before distribution in the body. Hence, i.v. and s.c. might result in more delayed metabolism and potentially a more durable action of $\mathrm{Rg} 3$ itself compared to the other routes of administration. However, even with a single i.v. administration, $\operatorname{Rg} 3$ metabolites, ginsenoside- $\mathrm{Rh} 2$ and protopanaxadiol, were almost instantly detected in the blood [100]. We already know that these molecules have anti-tumor and anti-angiogenic properties [107-109]. This raises the question, are the anti-angiogenic effects of $\mathrm{Rg} 3$ in vivo due to $\mathrm{Rg} 3$, its metabolites, or a combination of all? In that case, $\mathrm{Rg} 3$ is potentially not only a drug but also a prodrug.

Half-life of Rg3 following i.v. administration was studied in Sprague-Dawley rats. With $10 \mathrm{mg} / \mathrm{kg}$, $\mathrm{Rg} 3$ showed a two-compartment pharmacokinetic model with half-lives of about $12 \mathrm{~min}$ and $2 \mathrm{~h}$ [103]. With $5 \mathrm{mg} / \mathrm{kg}$, the half-life was reported to be about 14-18.5 $\mathrm{min}[104,105]$. This shows that $\mathrm{Rg} 3$ has a generally short half-life in rats. Furthermore, the highest reported $\mathrm{C}_{\max }$ in human study is about $400 \mathrm{ng} / \mathrm{mL}$ [110]. This is a very low concentration, equal to almost $5 \times 10^{-7} \mathrm{nM}$. At this concentration, in vitro assays fail to show any efficacy of $\mathrm{Rg} 3$, and therefore it is possible to conclude that the efficacy of $\mathrm{Rg} 3$ is due to a combination of $\mathrm{Rg} 3$ and metabolites. This queries the sufficiency of the dosing schedule in many of the animal studies (Table 2). Administration of a single dose per day or even one dose per 3 days seems to be effective, but would they be as effective as administering $3-4$ doses per day?

\section{Safety of Rg3}

Regardless of the route of administration, Rg3 seems to be a safe drug. Acute toxicity testing of 800 and $1600 \mathrm{mg} / \mathrm{kg}$ of SRg3 (p.o.) to Sprague-Dawley rats and Kunming mice, respectively, showed no mortality or toxicity [111]. Repeated oral administration of 20,60 and $180 \mathrm{mg} / \mathrm{kg}$ SRg3 to Sprague-Dawley rats for 26 weeks showed no sign or symptoms of toxicity, with a no-observed-adverse-effect level (NOAEL) of $180 \mathrm{mg} / \mathrm{kg}$ [111]. Another toxicity study with 7, 20, or $60 \mathrm{mg} / \mathrm{kg}$ SRg3 (p.o.) was performed on Beagle dogs for 26 weeks and showed that SRg3 was safe. The only adverse finding was the increased but reversible kidney weight in dogs that received $60 \mathrm{mg} / \mathrm{kg} \mathrm{SRg}$. The NOAEL in this study was found to be $20 \mathrm{mg} / \mathrm{kg}$ [112], the human equivalent dose of which is approximately $11 \mathrm{mg} / \mathrm{kg}$. In healthy humans receiving intramuscular injections of $10-60 \mathrm{mg} / \mathrm{kg} \mathrm{SRg} 3$ as a single dose or $30 \mathrm{mg} / \mathrm{kg}$ once every two days for 15 days the drug was well tolerated with no detectable sign or symptoms of toxicity [110]. Furthermore, some clinical trials on non-small cell lung carcinoma $[113,114]$ and advanced hepatocellular carcinoma [115] have used Rg3 as orally administered anti-angiogenic agent, up to $50 \mathrm{mg} /$ day with no reported toxicity [113-115]. Therefore, $\operatorname{Rg} 3$ at these doses appears to be safe and well tolerated. 


\section{Conclusions}

From the literature, $\operatorname{Rg} 3$ has been shown to inhibit the proliferation and survival of endothelial cells and the expression of various factors involved in angiogenesis. The key driver of this process is the interaction between VEGF and VEGFR2. As discussed in this review paper, several in vitro and in vivo studies showed that Rg3 decreased the expression of these two molecules, and it could be postulated that this is the major mechanism of anti-angiogenic effect of Rg3. In addition, several other mechanisms are suggested including decreased expression of b-FGF, TGF- $\beta 1$, AQP1, JNK, Beclin-1, MMP-2, MMP-9 and Bcl-2. Rg3 also decreased the activation of various signaling pathways leading to activation of eNOS, including VEGF-induced Akt/eNOS, ER/PI3K/eNOS or AMPK/eNOS and decreased activation of PI3K/Akt/mTOR pathway, STAT3, ERK1/2 and JNK. It also decreased hsa-miR-520h-mediated expression of EphB2 and EphB4. With a few exceptions, studies describe this anti-angiogenic effect at $\mu \mathrm{M}$ range. Yet, some studies show $\mathrm{Rg} 3$ is effective at $\mathrm{nM}$ range too. This raises the question whether Rg3 has a biphasic or tri-phasic dose-response curve. In either case, higher efficacy of Rg3 in nM range is impressive, considering the low bioavailability following oral administration and high metabolism rate. It seems that administering the drug at $\mu \mathrm{M}$ doses leaves only $\mathrm{nM}$ concentrations in the blood, which is sufficient to exert the anti-cancer effects. Whether the metabolites of $\mathrm{Rg} 3$ also follow the same pattern is an unanswered question.

Considering the high rate of metabolism of $\mathrm{Rg} 3$, which leaves low levels of $\mathrm{Rg} 3$ in the blood, a dose-dependent anti-angiogenic effect at $\mathrm{nM}$ scale explains the observed in vivo anti-angiogenic effects, which could especially be potentiated by other metabolites of $\mathrm{Rg} 3$. Despite various in vivo reports supporting the anti-angiogenic action of $\operatorname{Rg} 3$, it should be taken into consideration that $\operatorname{Rg} 3$ is potentially a drug and a prodrug, which upon metabolism with active metabolites, ginsenoside Rh2 and PPD, could also contribute to the effects observed for Rg3. Therefore, the in vivo effects observed from this drug candidate could be attributed to a combination of $\mathrm{Rg} 3$ and its metabolites.

The final important issue is that Rg3 has two epimers with stereoselective activities, efficacies and pharmacokinetic profiles [100]. These epimers should be considered as two separate drugs; hence, the term $\operatorname{Rg} 3$ is vague and might not reflect the true nature and pharmacokinetic profile of the administered drug.

Author Contributions: Conceptualization, M.N. and J.E.H.; Writing-original draft preparation, M.N.; Writing-review and editing, M.N., E.S., A.R.T., T.J.P. and J.E.H.; Illustration, M.N. and J.E.H.; Supervision and mentoring, J.E.H., A.R.T. and T.J.P. All authors have read and agreed to the published version of the manuscript.

Funding: This research was funded by the Margaret Elcombe Hospital Research Foundation Research Grant.

Conflicts of Interest: The authors declare no conflict of interest.

\section{References}

1. Miao, X.S.; Metcalfe, C.D.; Hao, C.; March, R.E. Electrospray ionization mass spectrometry of ginsenosides. J. Mass Spectrom. 2002, 37, 495-506. [CrossRef]

2. Jo, S.K.; Kim, I.S.; Yoon, K.S.; Yoon, H.H.; Yoo, H.H. Preparation of ginsenosides Rg3, Rk1, and Rg5-selectively enriched ginsengs by a simple steaming process. Eur. Food Res. Technol. 2015, 240, 251-256. [CrossRef]

3. Chen, C.-f.; Chiou, W.-f.; Zhang, J.-t. Comparison of the pharmacological effects of Panax ginseng and Panax quinquefolium. Acta Pharmacol. Sin. 2008, 29, 1103-1108. [CrossRef] [PubMed]

4. Cheng, L.-Q.; Na, J.R.; Bang, M.H.; Kim, M.K.; Yang, D.-C. Conversion of major ginsenoside Rb1 to 20 (S)-ginsenoside Rg3 by Microbacterium sp. GS514. Phytochemistry 2008, 69, 218-224. [CrossRef] [PubMed]

5. Yan, Q.; Zhou, W.; Li, X.; Feng, M.; Zhou, P. Purification method improvement and characterization of a novel ginsenoside-hydrolyzing $\beta$-glucosidase from Paecilomyces Bainier sp. 229. Biosci. Biotechnol. Biochem. 2008, 72, 352-359. [CrossRef] [PubMed]

6. Jiang, Y.; Chen, J.; Ma, S.; Liu, K. Isolation and elucidation of alkaline degradation Product from total saponins in leaves and stems of Panax quinquefolium L. J. Guangzhou Univ. Tradit. Chin. Med. 2006, 19, 142-147.

7. Sun, C.; Gao, W.; Zhao, B.; Cheng, L. Optimization of the selective preparation of 20 (R)-ginsenoside Rg3 catalyzed by d, l-tartaric acid using response surface methodology. Fitoterapia 2013, 84, 213-221. [CrossRef] 
8. Bae, S.H.; Lee, H.-S.; Kim, M.-R.; Kim, S.Y.; Kim, J.-M.; Suh, H.J. Changes of ginsenoside content by mushroom mycelial fermentation in red ginseng extract. J. Ginseng Res. 2011, 35, 235-242. [CrossRef]

9. Lee, H.S.; Lee, H.J.; Yu, H.J.; Ju, D.W.; Kim, Y.; Kim, C.T.; Kim, C.J.; Cho, Y.J.; Kim, N.; Choi, S.Y. A comparison between high hydrostatic pressure extraction and heat extraction of ginsenosides from ginseng (Panax ginseng CA Meyer). J. Sci. Food Agric. 2011, 91, 1466-1473. [CrossRef]

10. Lee, S.A.; Jo, H.K.; Im, B.O.; Kim, S.; Whang, W.K.; Ko, S.K. Changes in the contents of prosapogenin in the red ginseng (Panax ginseng) depending on steaming batches. J. Ginseng Res. 2012, 36, 102-106. [CrossRef]

11. Nakhjavani, M.; Hardingham, J.E.; Palethorpe, H.M.; Tomita, Y.; Smith, E.; Price, T.J.; Townsend, A.R. Ginsenoside Rg3: Potential molecular targets and therapeutic indication in metastatic breast cancer. Medicines 2019, 6, 17. [CrossRef] [PubMed]

12. Nakhjavani, M.; Palethorpe, H.M.; Tomita, Y.; Smith, E.; Price, T.J.; Yool, A.J.; Pei, J.V.; Townsend, A.R.; Hardingham, J.E. Stereoselective Anti-Cancer Activities of Ginsenoside Rg3 on Triple Negative Breast Cancer Cell Models. Pharmaceuticals 2019, 12, 117. [CrossRef]

13. Kang, D.-I.; Lee, J.-Y.; Yang, J.-Y.; Jeong, S.M.; Lee, J.-H.; Nah, S.-Y.; Kim, Y. Evidence that the tertiary structure of 20 (S)-ginsenoside Rg3 with tight hydrophobic packing near the chiral center is important for $\mathrm{Na}+$ channel regulation. Biochem. Biophys. Res. Commun. 2005, 333, 1194-1201. [CrossRef] [PubMed]

14. Mochizuki, M.; Yoo, Y.C.; Matsuzawa, K.; Sato, K.; Saiki, I.; Tono-oka, S.; Samukawa, K.; Azuma, I. Inhibitory effect of tumor metastasis in mice by saponins, ginsenoside-Rb2, 20(R)- and 20(S)-ginsenoside-Rg3, of red ginseng. Biol. Pharm. Bull. 1995, 18, 1197-1202. [CrossRef] [PubMed]

15. Yue, P.Y.; Wong, D.Y.; Wu, P.K.; Leung, P.Y.; Mak, N.K.; Yeung, H.W.; Liu, L.; Cai, Z.; Jiang, Z.H.; Fan, T.P.; et al. The angiosuppressive effects of 20(R)- ginsenoside Rg3. Biochem. Pharmacol. 2006, 72, 437-445. [CrossRef] [PubMed]

16. Lee, J.J.; Kwon, H.K.; Jung, I.H.; Cho, Y.B.; Kim, K.J.; Kim, J.L. Anti-cancer Activities of Ginseng Extract Fermented with Phellinus linteus. Mycobiology 2009, 37, 21-27. [CrossRef] [PubMed]

17. Kim, J.W.; Jung, S.Y.; Kwon, Y.H.; Lee, J.H.; Lee, Y.M.; Lee, B.Y.; Kwon, S.M. Ginsenoside Rg3 attenuates tumor angiogenesis via inhibiting bioactivities of endothelial progenitor cells. Cancer Biol. Ther. 2012, 13, 504-515. [CrossRef]

18. Kim, J.W.; Jung, S.Y.; Kwon, Y.H.; Lee, S.H.; Lee, J.H.; Lee, B.Y.; Kwon, S.M. Ginsenoside Rg3 inhibits endothelial progenitor cell differentiation through attenuation of VEGF-dependent Akt/eNOS signaling. Phytother. Res. 2012, 26, 1286-1293. [CrossRef]

19. Keung, M.H.; Chan, L.S.; Kwok, H.H.; Wong, R.N.; Yue, P.Y. Role of microRNA-520h in 20(R)-ginsenoside-Rg3-mediated angiosuppression. J. Ginseng Res. 2016, 40, 151-159. [CrossRef]

20. Kwok, H.H.; Guo, G.L.; Lau, J.K.; Cheng, Y.K.; Wang, J.R.; Jiang, Z.H.; Keung, M.H.; Mak, N.K.; Yue, P.Y.; Wong, R.N. Stereoisomers ginsenosides-20(S)- $\operatorname{Rg}(3)$ and $-20(\mathrm{R})-\operatorname{Rg}(3)$ differentially induce angiogenesis through peroxisome proliferator-activated receptor-gamma. Biochem. Pharmacol. 2012, 83, 893-902. [CrossRef]

21. Hien, T.T.; Kim, N.D.; Pokharel, Y.R.; Oh, S.J.; Lee, M.Y.; Kang, K.W. Ginsenoside Rg3 increases nitric oxide production via increases in phosphorylation and expression of endothelial nitric oxide synthase: Essential roles of estrogen receptor-dependent PI3-kinase and AMP-activated protein kinase. Toxicol. Appl. Pharmacol. 2010, 246, 171-183. [CrossRef] [PubMed]

22. Li, J.P.; Zhao, F.L.; Yuan, Y.; Sun, T.T.; Zhu, L.; Zhang, W.Y.; Liu, M.X. Studies on anti-angiogenesis of ginsenoside structure modification HRG in vitro. Biochem. Biophys. Res. Commun. 2017, 492, 391-396. [CrossRef] [PubMed]

23. Sun, C.; Yu, Y.; Wang, L.; Wu, B.; Xia, L.; Feng, F.; Ling, Z.; Wang, S. Additive antiangiogenesis effect of ginsenoside Rg3 with low-dose metronomic temozolomide on rat glioma cells both in vivo and in vitro. J. Exp. Clin. Cancer Res. 2016, 35, 32. [CrossRef] [PubMed]

24. Duan, S.Z.; Usher, M.G.; Mortensen, R.M. PPARs: The vasculature, inflammation and hypertension. Curr. Opin. Nephrol. Hypertens. 2009, 18, 128-133. [CrossRef]

25. Calabrese, E.J. Estrogen and related compounds: Biphasic dose responses. Crit. Rev. Toxicol. 2001, 31, 503-515. [CrossRef]

26. Calabrese, E.J. Nitric oxide: Biphasic dose responses. Crit. Rev. Toxicol. 2001, 31, 489-501. [CrossRef] 
27. Hao, C.; Hao, W.; Wei, X.; Xing, L.; Jiang, J.; Shang, L. The role of MAPK in the biphasic dose-response phenomenon induced by cadmium and mercury in HEK293 cells. Toxicol. In Vitro 2009, 23, 660-666. [CrossRef]

28. Calabrese, E.J. Opiates: Biphasic dose responses. Crit. Rev. Toxicol. 2001, 31, 585-604. [CrossRef]

29. Calabrese, E.J. Dopamine: Biphasic dose responses. Crit. Rev. Toxicol. 2001, 31, 563-583. [CrossRef]

30. Celik, I.; Sürücü, O.; Dietz, C.; Heymach, J.V.; Force, J.; Höschele, I.; Becker, C.M.; Folkman, J.; Kisker, O. Therapeutic efficacy of endostatin exhibits a biphasic dose-response curve. Cancer Res. 2005, 65, 11044-11050. [CrossRef]

31. Weis, M.; Heeschen, C.; Glassford, A.J.; Cooke, J.P. Statins have biphasic effects on angiogenesis. Circulation 2002, 105, 739-745. [CrossRef]

32. Volpert, O.V.; Ward, W.F.; Lingen, M.W.; Chesler, L.; Solt, D.B.; Johnson, M.D.; Molteni, A.; Polverini, P.J.; Bouck, N.P. Captopril inhibits angiogenesis and slows the growth of experimental tumors in rats. J. Clin. Investig. 1996, 98, 671-679. [CrossRef] [PubMed]

33. Slaton, J.W.; Perrotte, P.; Inoue, K.; Dinney, C.P.; Fidler, I.J. Interferon- $\alpha$-mediated down-regulation of angiogenesis-related genes and therapy of bladder cancer are dependent on optimization of biological dose and schedule. Clin. Cancer Res. 1999, 5, 2726-2734.

34. Takayasu, M.; Kajita, Y.; Suzuki, Y.; Shibuya, M.; Sugita, K.; Ishikawa, T.; Hidaka, H. Triphasic response of rat intracerebral arterioles to increasing concentrations of vasopressin in vitro. J. Cereb. Blood Flow Metab. 1993, 13, 304-309. [CrossRef]

35. Oishi, M.; Inagaki, C.; Fujiwara, M.; Takaori, S.; Yajima, H.; Akazawa, Y. Possible mechanisms of the triphasic effects of neurotensin on the rat blood pressure. Jpn. J. Pharmacol. 1981, 31, 1043-1049. [CrossRef]

36. James, R.C.; Franklin, M.R. The triphasic amphetamine lethal dose curve in mice and its possible relationship to drug metabolism. Toxicol. Appl. Pharmacol. 1978, 44, 63-73. [CrossRef]

37. Marech, I.; Leporini, C.; Ammendola, M.; Porcelli, M.; Gadaleta, C.D.; Russo, E.; De Sarro, G.; Ranieri, G. Classical and non-classical proangiogenic factors as a target of antiangiogenic therapy in tumor microenvironment. Cancer Lett. 2016, 380, 216-226. [CrossRef] [PubMed]

38. Yu, Y.; Zhang, C.; Liu, L.; Li, X. Hepatic arterial administration of ginsenoside Rg3 and transcatheter arterial embolization for the treatment of VX2 liver carcinomas. Exp. Ther. Med. 2013, 5, 761-766. [CrossRef]

39. Chen, Q.J.; Zhang, M.Z.; Wang, L.X. Gensenoside Rg3 inhibits hypoxia-induced VEGF expression in human cancer cells. Cell. Physiol. Biochem. 2010, 26, 849-858. [CrossRef]

40. Wu, W.; Zhou, Q.; Zhao, W.; Gong, Y.; Su, A.; Liu, F.; Liu, Y.; Li, Z.; Zhu, J. Ginsenoside Rg3 Inhibition of Thyroid Cancer Metastasis Is Associated with Alternation of Actin Skeleton. J. Med. Food 2018, 21, 849-857. [CrossRef]

41. Tang, M.; Wang, W.; Cheng, L.; Jin, R.; Zhang, L.; Bian, W.; Zhang, Y. The inhibitory effects of 20(R)-ginsenoside $\mathrm{Rg} 3$ on the proliferation, angiogenesis, and collagen synthesis of hypertrophic scar derived fibroblasts in vitro. Iran. J. Basic Med. Sci. 2018, 21, 309-317. [CrossRef] [PubMed]

42. Breen, E.; Tang, K.; Olfert, M.; Knapp, A.; Wagner, P. Skeletal muscle capillarity during hypoxia: VEGF and its activation. High. Alt. Med. Biol. 2008, 9, 158-166. [CrossRef] [PubMed]

43. Williams, C.S.; Tsujii, M.; Reese, J.; Dey, S.K.; DuBois, R.N. Host cyclooxygenase-2 modulates carcinoma growth. J. Clin. Investig. 2000, 105, 1589-1594. [CrossRef] [PubMed]

44. Simons, M.; Gordon, E.; Claesson-Welsh, L. Mechanisms and regulation of endothelial VEGF receptor signalling. Nat. Rev. Mol. Cell Biol. 2016, 17, 611. [CrossRef] [PubMed]

45. Shibuya, M. VEGFR and type-V RTK activation and signaling. Cold Spring Harb. Perspect. Biol. 2013, 5, a009092. [CrossRef] [PubMed]

46. Nilsson, M.; Heymach, J.V. Vascular endothelial growth factor (VEGF) pathway. J. Thorac. Oncol. 2006, 1, 768-770. [CrossRef]

47. Zhuang, G.; Yu, K.; Jiang, Z.; Chung, A.; Yao, J.; Ha, C.; Toy, K.; Soriano, R.; Haley, B.; Blackwood, E. Phosphoproteomic analysis implicates the mTORC2-FoxO1 axis in VEGF signaling and feedback activation of receptor tyrosine kinases. Sci. Signal. 2013, 6, ra25. [CrossRef] [PubMed]

48. Rodrigues, S.F.; Granger, D.N. Blood cells and endothelial barrier function. Tissue Barriers 2015, 3, e978720. [CrossRef]

49. Zhang, Q.; Kang, X.; Yang, B.; Wang, J.; Yang, F. Antiangiogenic effect of capecitabine combined with ginsenoside Rg3 on breast cancer in mice. Cancer Biother. Radiopharm. 2008, 23, 647-653. [CrossRef] 
50. Zhang, Y.; Liu, Q.Z.; Xing, S.P.; Zhang, J.L. Inhibiting effect of Endostar combined with ginsenoside Rg3 on breast cancer tumor growth in tumor-bearing mice. Asian Pac. J. Trop. Med. 2016, 9, 180-183. [CrossRef]

51. Xu, T.M.; Xin, Y.; Cui, M.H.; Jiang, X.; Gu, L.P. Inhibitory effect of ginsenoside Rg3 combined with cyclophosphamide on growth and angiogenesis of ovarian cancer. Chin. Med. J. (Engl.) 2007, 120, 584-588. [CrossRef]

52. Xu, T.M.; Cui, M.H.; Xin, Y.; Gu, L.P.; Jiang, X.; Su, M.M.; Wang, D.D.; Wang, W.J. Inhibitory effect of ginsenoside Rg3 on ovarian cancer metastasis. Chin. Med. J. (Engl.) 2008, 121, 1394-1397. [CrossRef]

53. Cao, Y.; Ye, Q.; Zhuang, M.; Xie, S.; Zhong, R.; Cui, J.; Zhou, J.; Zhu, Y.; Zhang, T.; Cao, L. Ginsenoside $\mathrm{Rg} 3$ inhibits angiogenesis in a rat model of endometriosis through the VEGFR-2-mediated PI3K/Akt/mTOR signaling pathway. PLoS ONE 2017, 12, e0186520. [CrossRef] [PubMed]

54. Tang, Y.C.; Zhang, Y.; Zhou, J.; Zhi, Q.; Wu, M.Y.; Gong, F.R.; Shen, M.; Liu, L.; Tao, M.; Shen, B.; et al. Ginsenoside Rg3 targets cancer stem cells and tumor angiogenesis to inhibit colorectal cancer progression in vivo. Int. J. Oncol. 2018, 52, 127-138. [CrossRef] [PubMed]

55. Liu, T.; Duo, L.; Duan, P. Ginsenoside Rg3 Sensitizes Colorectal Cancer to Radiotherapy through Downregulation of Proliferative and Angiogenic Biomarkers. Evid. Based Complement. Alternat. Med. 2018, 2018, 1580427. [CrossRef]

56. Liu, T.G.; Huang, Y.; Cui, D.D.; Huang, X.B.; Mao, S.H.; Ji, L.L.; Song, H.B.; Yi, C. Inhibitory effect of ginsenoside Rg3 combined with gemcitabine on angiogenesis and growth of lung cancer in mice. BMC Cancer 2009, 9, 250. [CrossRef] [PubMed]

57. Yu, H.; Teng, L.; Meng, Q.; Li, Y.; Sun, X.; Lu, J.; R, J.L.; Teng, L. Development of liposomal Ginsenoside Rg3: Formulation optimization and evaluation of its anticancer effects. Int. J. Pharm. 2013, 450, 250-258. [CrossRef] [PubMed]

58. Chen, J.; Peng, H.; Ou-Yang, X.; He, X. Research on the antitumor effect of ginsenoside Rg3 in B16 melanoma cells. Melanoma Res. 2008, 18, 322-329. [CrossRef]

59. Meng, L.; Ji, R.; Dong, X.; Xu, X.; Xin, Y.; Jiang, X. Antitumor activity of ginsenoside Rg3 in melanoma through downregulation of the ERK and Akt pathways. Int. J. Oncol. 2019, 54, 2069-2079. [CrossRef]

60. Zhou, B.; Wang, J.; Yan, Z. Ginsenoside Rg3 attenuates hepatoma VEGF overexpression after hepatic artery embolization in an orthotopic transplantation hepatocellular carcinoma rat model. Onco Targets Ther. 2014, 7, 1945-1954. [CrossRef]

61. Hu, S.; Zhu, Y.; Xia, X.; Xu, X.; Chen, F.; Miao, X.; Chen, X. Ginsenoside Rg3 Prolongs Survival of the Orthotopic Hepatocellular Carcinoma Model by Inducing Apoptosis and Inhibiting Angiogenesis. Anal. Cell. Pathol. (Amst.) 2019, 2019, 3815786. [CrossRef] [PubMed]

62. Murohara, T.; Asahara, T.; Silver, M.; Bauters, C.; Masuda, H.; Kalka, C.; Kearney, M.; Chen, D.; Symes, J.; Fishman, M. Nitric oxide synthase modulates angiogenesis in response to tissue ischemia. J. Clin. Investig. 1998, 101, 2567-2578. [CrossRef] [PubMed]

63. Papapetropoulos, A.; García-Cardeña, G.; Madri, J.A.; Sessa, W.C. Nitric oxide production contributes to the angiogenic properties of vascular endothelial growth factor in human endothelial cells. J. Clin. Investig. 1997, 100, 3131-3139. [CrossRef] [PubMed]

64. Gerber, H.-P.; McMurtrey, A.; Kowalski, J.; Yan, M.; Keyt, B.A.; Dixit, V.; Ferrara, N. Vascular endothelial growth factor regulates endothelial cell survival through the phosphatidylinositol 3'-kinase/Akt signal transduction pathway requirement for Flk-1/KDR activation. J. Biol. Chem. 1998, 273, 30336-30343. [CrossRef]

65. Michell, B.; Griffiths, J.; Mitchelhill, K.; Rodriguez-Crespo, I.; Tiganis, T.; Bozinovski, S.; de Montellano, P.O.; Kemp, B.; Pearson, R. The Akt kinase signals directly to endothelial nitric oxide synthase. Curr. Biol. 1999, 9, 845-848. [CrossRef]

66. Kim, N.D.; Kang, S.Y.; Schini, V.B. Ginsenosides evoke endothelium-dependent vascular relaxation in rat aorta. Gen. Pharmacol. 1994, 25, 1071-1077. [CrossRef]

67. Kang, Y.J.; Sohn, J.-T.; Chang, K.C. Relaxation of canine corporal smooth muscle relaxation by ginsenoside saponin Rg3 is independent from eNOS activation. Life Sci. 2005, 77, 74-84. [CrossRef] [PubMed]

68. Lu, M.; Fei, Z.; Zhang, G. Synergistic anticancer activity of 20 (S)-Ginsenoside Rg3 and Sorafenib in hepatocellular carcinoma by modulating PTEN/Akt signaling pathway. Biomed. Pharmacother. 2018, 97, 1282-1288. [CrossRef] 
69. Hisamoto, K.; Ohmichi, M.; Kurachi, H.; Hayakawa, J.; Kanda, Y.; Nishio, Y.; Adachi, K.; Tasaka, K.; Miyoshi, E.; Fujiwara, N. Estrogen induces the Akt-dependent activation of endothelial nitric-oxide synthase in vascular endothelial cells. J. Biol. Chem. 2001, 276, 3459-3467. [CrossRef]

70. Applanat, M.P.; Buteau-Lozano, H.; Herve, M.A.; Corpet, A. Vascular endothelial growth factor is a target gene for estrogen receptor and contributes to breast cancer progression. In Hormonal Carcinogenesis $V$; Springer: Berlin/Heidelberg, Germany, 2008; pp. 437-444.

71. Mueller, M.D.; Vigne, J.-L.; Minchenko, A.; Lebovic, D.I.; Leitman, D.C.; Taylor, R.N. Regulation of vascular endothelial growth factor (VEGF) gene transcription by estrogen receptors $\alpha$ and $\beta$. Proc. Natl. Acad. Sci. USA 2000, 97, 10972-10977. [CrossRef]

72. Zarubin, T.; Jiahuai, H. Activation and signaling of the p38 MAP kinase pathway. Cell Res. 2005, 15, 11-18. [CrossRef] [PubMed]

73. Shen, K.; Ji, L.; Lu, B.; Wang, Z. c-Jun N-terminal kinase mediated VEGFR2 sustained phosphorylation is critical for VEGFA-induced angiogenesis in vitro and in vivo. Cell Biochem. Biophys. 2012, 64, 17-27. [CrossRef] [PubMed]

74. Park, J.-H.; Park, M.; Byun, C.J.; Jo, I. c-Jun N-terminal kinase 2 phosphorylates endothelial nitric oxide synthase at serine 116 and regulates nitric oxide production. Biochem. Biophys. Res. Commun. 2012, 417, 340-345. [CrossRef] [PubMed]

75. Gee, E.; Milkiewicz, M.; Haas, T.L. p38 MAPK activity is stimulated by vascular endothelial growth factor receptor 2 activation and is essential for shear stress-induced angiogenesis. J. Cell. Physiol. 2010, 222, 120-126. [CrossRef]

76. Chrestensen, C.A.; McMurry, J.L.; Salerno, J.C. MAP kinases bind endothelial nitric oxide synthase. FEBS Open Bio. 2012, 2, 51-55. [CrossRef] [PubMed]

77. Nagata, D.; Mogi, M.; Walsh, K. AMP-activated protein kinase (AMPK) signaling in endothelial cells is essential for angiogenesis in response to hypoxic stress. J. Biol. Chem. 2003, 278, 31000-31006. [CrossRef]

78. Morrow, V.A.; Foufelle, F.; Connell, J.M.; Petrie, J.R.; Gould, G.W.; Salt, I.P. Direct activation of AMP-activated protein kinase stimulates nitric-oxide synthesis in human aortic endothelial cells. J. Biol. Chem. 2003, 278, 31629-31639. [CrossRef]

79. Laplante, M.; Sabatini, D.M. mTOR signaling at a glance. J. Cell Sci. 2009, 122, 3589-3594. [CrossRef]

80. Karar, J.; Maity, A. PI3K/AKT/mTOR pathway in angiogenesis. Front. Mol. Neurosci. 2011, 4, 51. [CrossRef]

81. Chen, Z.; Han, Z.C. STAT3: A critical transcription activator in angiogenesis. Med. Res. Rev. 2008, 28, 185-200. [CrossRef]

82. Tang, M.; Bian, W.; Cheng, L.; Zhang, L.; Jin, R.; Wang, W.; Zhang, Y. Ginsenoside Rg3 inhibits keloid fibroblast proliferation, angiogenesis and collagen synthesis in vitro via the TGFbeta/Smad and ERK signaling pathways. Int. J. Mol. Med. 2018, 41, 1487-1499. [CrossRef]

83. Tomita, Y.; Dorward, H.; Yool, A.J.; Smith, E.; Townsend, A.R.; Price, T.J.; Hardingham, J.E. Role of aquaporin 1 signalling in cancer development and progression. Int. J. Mol. Sci. 2017, 18, 299. [CrossRef]

84. De Ieso, M.L.; Yool, A.J. Mechanisms of aquaporin-facilitated cancer invasion and metastasis. Front. Chem. 2018, 6, 135. [CrossRef]

85. Perego, C.; Vanoni, C.; Massari, S.; Longhi, R.; Pietrini, G. Mammalian LIN-7 PDZ proteins associate with $\beta$-catenin at the cell-cell junctions of epithelia and neurons. EMBO J. 2000, 19, 3978-3989. [CrossRef]

86. Monzani, E.; Bazzotti, R.; Perego, C.; La Porta, C.A. AQP1 is not only a water channel: It contributes to cell migration through Lin7/beta-catenin. PLOS ONE 2009, 4. [CrossRef]

87. Meng, F.; Rui, Y.; Xu, L.; Wan, C.; Jiang, X.; Li, G. Aqp1 enhances migration of bone marrow mesenchymal stem cells through regulation of FAK and $\beta$-catenin. Stem Cells Dev. 2014, 23, 66-75. [CrossRef]

88. Wei, X.; Dong, J. Aquaporin 1 promotes the proliferation and migration of lung cancer cell in vitro. Oncol. Rep. 2015, 34, 1440-1448. [CrossRef]

89. Galán-Cobo, A.; Ramírez-Lorca, R.; Toledo-Aral, J.J.; Echevarría, M. Aquaporin-1 plays important role in proliferation by affecting cell cycle progression. J. Cell. Physiol. 2016, 231, 243-256. [CrossRef]

90. Almasalmeh, A.; Krenc, D.; Wu, B.; Beitz, E. Structural determinants of the hydrogen peroxide permeability of aquaporins. FEBS J. 2014, 281, 647-656. [CrossRef]

91. Tafani, M.; Sansone, L.; Limana, F.; Arcangeli, T.; De Santis, E.; Polese, M.; Fini, M.; Russo, M.A. The interplay of reactive oxygen species, hypoxia, inflammation, and sirtuins in cancer initiation and progression. Oxid. Med. Cell. Longev. 2016, 2016. [CrossRef] 
92. Schenk, B.; Fulda, S. Reactive oxygen species regulate Smac mimetic/TNF $\alpha$-induced necroptotic signaling and cell death. Oncogene 2015, 34, 5796-5806. [CrossRef]

93. Clapp, C.; de la Escalera, G.M. Aquaporin-1: A novel promoter of tumor angiogenesis. Trends Endocrinol. Metab. 2006, 17, 1-2. [CrossRef] [PubMed]

94. Saadoun, S.; Papadopoulos, M.C.; Hara-Chikuma, M.; Verkman, A. Impairment of angiogenesis and cell migration by targeted aquaporin-1 gene disruption. Nature 2005, 434, 786-792. [CrossRef]

95. Abreu-Rodríguez, I.; Silva, R.S.; Martins, A.P.; Soveral, G.; Toledo-Aral, J.J.; López-Barneo, J.; Echevarría, M. Functional and transcriptional induction of aquaporin-1 gene by hypoxia; analysis of promoter and role of Hif-1 $\alpha$. PLoS ONE 2011, 6, e28385. [CrossRef]

96. Dorward, H.S.; Du, A.; Bruhn, M.A.; Wrin, J.; Pei, J.V.; Evdokiou, A.; Price, T.J.; Yool, A.J.; Hardingham, J.E. Pharmacological blockade of aquaporin-1 water channel by AqB013 restricts migration and invasiveness of colon cancer cells and prevents endothelial tube formation in vitro. J. Exp. Clin. Cancer Res. 2016, 35, 36. [CrossRef]

97. Tomita, Y.; Palethorpe, H.M.; Smith, E.; Nakhjavani, M.; Townsend, A.R.; Price, T.J.; Yool, A.J.; Hardingham, J.E. Bumetanide-derived aquaporin 1 inhibitors, aqb013 and aqb050 inhibit tube formation of endothelial cells through induction of apoptosis and impaired migration in vitro. Int. J. Mol. Sci. 2019, 20, 1818. [CrossRef]

98. Palethorpe, H.M.; Tomita, Y.; Smith, E.; Pei, J.V.; Townsend, A.R.; Price, T.J.; Young, J.P.; Yool, A.J.; Hardingham, J.E. The aquaporin 1 inhibitor bacopaside II reduces endothelial cell migration and tubulogenesis and induces apoptosis. Int. J. Mol. Sci. 2018, 19, 653. [CrossRef]

99. Pan, X.-Y.; Guo, H.; Han, J.; Hao, F.; An, Y.; Xu, Y.; Xiaokaiti, Y.; Pan, Y.; Li, X.-J. Ginsenoside Rg3 attenuates cell migration via inhibition of aquaporin 1 expression in PC-3M prostate cancer cells. Eur. J. Pharmacol. 2012, 683, 27-34. [CrossRef]

100. Peng, M.; Li, X.; Zhang, T.; Ding, Y.; Yi, Y.; Le, J.; Yang, Y.; Chen, X. Stereoselective pharmacokinetic and metabolism studies of 20 (S)-and 20 (R)-ginsenoside Rg3 epimers in rat plasma by liquid chromatography-electrospray ionization mass spectrometry. J. Pharm. Biomed. Anal. 2016, 121, 215-224. [CrossRef]

101. Yang, L.; Zhang, X.-y.; Li, K.; Li, A.-p.; Yang, W.-d.; Yang, R.; Wang, P.; Zhao, Z.-h.; Cui, F.; Qin, Y. Protopanaxadiol inhibits epithelial-mesenchymal transition of hepatocellular carcinoma by targeting STAT3 pathway. Cell Death Dis. 2019, 10, 1-13. [CrossRef]

102. Chen, Y.; Zhang, Y.; Song, W.; Zhang, Y.; Dong, X.; Tan, M. Ginsenoside Rh2 Inhibits Migration of Lung Cancer Cells under Hypoxia via mir-491. Anti-Cancer Agents Med. Chem. 2019, 19, 1633-1641. [CrossRef] [PubMed]

103. Xie, H.-T.; Wang, G.-J.; Sun, J.-G.; Tucker, I.; Zhao, X.-C.; Xie, Y.-Y.; Li, H.; Jiang, X.-l.; Wang, R.; Xu, M.-J. High performance liquid chromatographic-mass spectrometric determination of ginsenoside Rg3 and its metabolites in rat plasma using solid-phase extraction for pharmacokinetic studies. J. Chromatogr. B 2005, 818, 167-173. [CrossRef] [PubMed]

104. Cai, Z.; Qian, T.; Wong, R.N.; Jiang, Z.-H. Liquid chromatography-electrospray ionization mass spectrometry for metabolism and pharmacokinetic studies of ginsenoside Rg3. Anal. Chim. Acta 2003, 492, 283-293. [CrossRef]

105. Qian, T.; Cai, Z.; Wong, R.N.; Mak, N.K.; Jiang, Z.-H. In vivo rat metabolism and pharmacokinetic studies of ginsenoside Rg3. J. Chromatogr. B 2005, 816, 223-232. [CrossRef]

106. Lipinski, C.A.; Lombardo, F.; Dominy, B.W.; Feeney, P.J. Experimental and computational approaches to estimate solubility and permeability in drug discovery and development settings. Adv. Drug Deliv. Rev. 1997, 23, 3-25. [CrossRef]

107. Li, G.; Wang, Z.; Sun, Y.; Liu, K.; Wang, Z. Ginsenoside 20 (S)-protopanaxadiol inhibits the proliferation and invasion of human fibrosarcoma HT1080 cells. Basic Clin. Pharmacol. Toxicol. 2006, 98, 588-592. [CrossRef] [PubMed]

108. Chen, X.-J.; Zhang, X.-J.; Shui, Y.-M.; Wan, J.-B.; Gao, J.-L. Anticancer activities of protopanaxadiol-and protopanaxatriol-type ginsenosides and their metabolites. Evid. Based Complement. Alternat. Med. 2016, 2016. [CrossRef]

109. Huang, Y.; Huang, H.; Han, Z.; Li, W.; Mai, Z.; Yuan, R. Ginsenoside Rh2 inhibits angiogenesis in prostate cancer by targeting CNNM1. J. Nanosci. Nanotechnol. 2019, 19, 1942-1950. [CrossRef] 
110. Zhao, Q.; Li, P.; Jiang, J.; Hu, P. Pharmacokinetics of single ascending doses and multiple doses of 20 (S)-ginsenoside Rg3 in Chinese healthy volunteers. Eur. J. Drug Metab. Pharmacokinet. 2016, 41, 845-853. [CrossRef]

111. Li, C.; Wang, Z.; Li, G.; Wang, Z.; Yang, J.; Li, Y.; Wang, H.; Jin, H.; Qiao, J.; Wang, H. Acute and repeated dose 26-week oral toxicity study of 20 (S)-ginsenoside Rg3 in Kunming mice and Sprague-Dawley rats. J. Ginseng Res. 2020, 44, 222-228. [CrossRef]

112. Gao, Y.; Wang, G.; Wang, T.; Li, G.; Lin, J.; Sun, L.; Wu, X.; Sun, X.; Wang, H.; Li, C. A 26-week 20 (S)-ginsenoside Rg3 oral toxicity study in Beagle dogs. Regul. Toxicol. Pharmacol. 2020, 110, 104522. [CrossRef]

113. Lu, P.; Su, W.; Miao, Z.-h.; Niu, H.-r.; Liu, J.; Hua, Q.-l. Effect and mechanism of ginsenoside Rg3 on postoperative life span of patients with non-small cell lung cancer. Chin. J. Integr. Med. 2008, 14, 33-36. [CrossRef] [PubMed]

114. Li, Y.; Wang, Y.; Niu, K.; Chen, X.; Xia, L.; Lu, D.; Kong, R.; Chen, Z.; Duan, Y.; Sun, J. Clinical benefit from EGFR-TKI plus ginsenoside Rg3 in patients with advanced non-small cell lung cancer harboring EGFR active mutation. Oncotarget 2016, 7, 70535. [CrossRef]

115. Zhou, B.; Yan, Z.; Liu, R.; Shi, P.; Qian, S.; Qu, X.; Zhu, L.; Zhang, W.; Wang, J. Prospective study of transcatheter arterial chemoembolization (TACE) with ginsenoside Rg3 versus TACE alone for the treatment of patients with advanced hepatocellular carcinoma. Radiology 2016, 280, 630-639. [CrossRef]

Sample Availability: Samples of the compounds are not available from the authors.

Publisher's Note: MDPI stays neutral with regard to jurisdictional claims in published maps and institutional affiliations.

(C) 2020 by the authors. Licensee MDPI, Basel, Switzerland. This article is an open access article distributed under the terms and conditions of the Creative Commons Attribution (CC BY) license (http://creativecommons.org/licenses/by/4.0/). 